4. Москаленко В. Художня функція фактури (до визначення поняття). Науковий вісник. Нац. муз. акад. України ім. П.І. Чайковського. Київ, 2000. Вип. 7. С. 56-65.

5. Назайкинский Е. В. Звуковой мир музыки. Москва: Музыка, 1988. $256 \mathrm{c}$.

6. Назайкинский Е.В. Логика музыкальной композиции. Москва : Музыка, 1982. 319 с.

7. Нейгауз Г. Об искусстве фортепианной игры: записки педагога. Москва : Музыка, 1988. 240 с.

8. Холопова В. Н. Фактура: очерк. Москва : Музыка, 1979. 88 с.

DOI https://doi.org/10.30525/978-9934-26-004-9-121

\title{
ОПЕРНА ШЕВЧЕНКІАНА МИХАЙЛА ВЕРИКІВСЬКОГО
}

\author{
Боровик С. Й. \\ заслужена артистка Украӥни, доцент, \\ завідуюча кафедри академічного співу та хорового диригування \\ Київської муніциипальної академії музики імені Р. М. Глієра \\ м. Київ, Україна
}

Український митець Михайло Вериківський - видатний композитор першої половини XX століття. В його спадщині оперно-театральні твори займають провідне місце. Як диригент М. Вериківський працював у видатних музичних та драматичних експериментальних театрах, серед яких: «Березіль» під орудою Леся Курбаса, Харківський Театр революції, Театр-студія імені $Г$. Михайличенка, тому цілком природньою $\epsilon$ зацікавленість митця саме цією жанровою сферою.

М. Вериківський має у власному доробку п'ять ліричних опер на сюжети українських письменників та одну сатиричну - гумористичний скетч «Діли небесні» за О. Вишнею, а також музику до театральних вистав «Жакерія», «Жандарм», «Сорочинський ярмарок», «Прокламація сезону», «Таланти без прихильників», «Пісня партизан», «Трест Д. Е.», «Ой не ходи, Грицю», «Чорні хлопці», «Універсальний некрополь», та інші. Усі хрестоматійні українські художні фільми «Тарас Шевченко», «Назар Стодоля», «Устим Кармелюк», «Київ», були озвучені кіномузикою М. Вериківського, а до екранізації опери С. Гулака-Артемовського «Запорожець за Дунаєм» композитор створив вставні номери.

На жаль, підвалини вивчення оперної спадщини Вериківського, що були закладені у другій половині XX століття, не отримали розгортання 
у науковій практиці сучасності. Відмітимо декілька аналітичних робіт 60-х-80-х років минулого століття, які вдало розкривають спорідненість мислення композитора українському ментальному простору, особливо у його оперній шевченкіані (Герасимова-Персидська, 1966 [2]; Шольп, 1968 [3]; Толошняк, 1986 [4]).

Сьогодні існує велика кількість білих плям щодо осмислення оперної творчості Вериківського. Не зовсім повною навіть $є$ загальна інформація про оперний доробок композитора та про його численні музичнотеатральні проекти. Завдячуючи відомостям, що на підставі аналізу архівів композитора надає Ю. Бентя [1, с. 76-80], можна відновити цілісну картину існування оперного жанру, його моделей та різновидів у доробку М. Вериківського, в історичній тяглости творчої еволюції композитора.

Першу свою оперу «Лісова пісня» М. Вериківський написав за однойменною драмою Лесі Українки у 1925 році, вона існує у клавірі. Ïї друга редакція зроблена у воєнні часи (1943-1945). Протягом 30-х років завершено наступні опери: «Діли небесні» на лібрето Остапа Вишні (1931); «Вій» на власне лібрето за повістю М. Гоголя (І редакція 1936-1937; II редакція - 1945-1946); опера «Сотник» на власне лібрето за поемою Т. Г. Шевченка з умовною назвою «У Оглаві...» (1938). Також у цей період М. Вериківський розпочав роботу над оперою «Наймичка». Робота продовжувалась значний період часу: з 1939 по1959 роки.

У 40-х роках композитор переважно зосереджений на камерних моделях оперного жанру. Саме у цьому дусі написані музична драма «Оргія» за Лесею Українкою та два оперних етюди «Байка про Будяка й Троянду» (на текст Л. Глібова) i «Втікачі» (за оповіданням М. Коцюбинського «Дорогою ціною»). Особливий жанровий стиль притаманний так званим оперним етюдам, в яких немає жодної кантиленної аріозної побудови у вокальних партіях. В оперних етюдах М. Вериківського присутні лише речитативи. Для композитора важливим був синтез музики і прозового тексту, коли «співане слово за інтонацією схоже на розмовне».

У 50-х роках автор повертається до творів великої форми і працює над трьохактною оперою «Карнавал у Сент-Іштвані» за новелою «Ілонка» О. Гончара, та оперою «Слава» на чотири дії на власне лібрето за однойменною п'єсою В. Гусєва. Залишилося декілька музичних фрагментів опер п'ятидесятих років, це «Безіменна зірка» і «Тарас Бульба».

Особливе місце в оперній творчості М. Вериківського займають сюжети Тараса Шевченка та Миколи Гоголя. Одноактна опера «Сотник» на лібрето композитора, зосереджена навкруги лірико-побутового аспекту та своєрідного селянського «любовного трикутника»: старого сотника, його сина Петра та Насті. Згідно сюжету поеми Т. Шевченка «У Оглаві ...», старий сотник, вдівець, виховує прийомну дівчину 202 
Настусю. Мріям сотника побратися з нею заважає його рідний син, який повертається 3 навчання з Києва. Молоді люди покохали одне одного i втекли 3 дому старика-сотника. Родзинкою музики опери $є$ незвичайно яскрава характеристика Настусі. Чоловічі ролі другорядні, їх музичні репліки переважно речитативні, тому провідною в опері $\epsilon$ роль та вокальна партія Настусі. Вона має яскраву музичну характеристику, наближену до народно-пісенного мелосу. Н. Герасимова-Персидська також відмічає особливу виразність ладового колориту опери: «Типова для змісту народних пісень поступова драматизація, виразно відчутна в шевченківському тексті, підкреслена появою у кульмінації елементів гармонічного ладу, а також VI підвищеного ступеня, що “додає жалощів" (за висловом Остапа Вересая)» [2, с. 67]. Прем’єра відбулася 1939 р. в Одесі силами диригента Є. Дубленського, режисера А. Шольна, художника В. Чікова.

Видатна опера М. Вериківського «Наймичка» написана в 1940 р. за поемою Т. Шевченка. В опері розкрита типова тема шевченкової поезії, яка торкається долі жінки, її безпорадності. Приховуючи гірку таємницю власної долі покритки, Ганна, героїня поеми, стає наймичкою в домі названих батьків свого покинутого сина. У власному лібрето М. Вериківський використав більшу частину поеми Шевченка, а окремі епізоди написав поет К. Герасименко. Опера складається з п’яти картин, провідним $є$ образ Ганни, який яскраво втілює трагедійну вершину опери, уособлюючи у долі усіх жінок образ України. Драматична кульмінація - це колискова Ганни, одна з творчих вдач композитора. Видатні співаки, що приймали участь у постановці опери у роки війни у 1943 році в місті Іркутськ, згадують про свої враження від неймовірної сили драматургічного узагальнення провідного образу та ідеї опери. Прем’єра опери «Наймичка» відбулася в евакуації силами диригента В. Тольби, режисера В. Манзій, художника А. Хвостенко-Хвостова. I. С. Паторжинський згадує, як щось боляче стиснуло горло, коли «Ганна» - Марія Литвиненко-Вольгемут співала свою трагічну колискову.

У створенні всіх образів опери важливу роль відіграє народний мелос. Зв'язок аріозних побудов вокальної лінії героїні опери з народною пісенністю визначив ту органічність, 3 якою вплітаються в музичну тканину опери хорові народні пісні, наприклад, уся обрядова сцена, хори чумаків з першої картини і дівчат з другої.

Пізніше М. Вериківський, незадоволений побудовою лібрето, створив другу редакцію опери, де досяг більшої драматургічної цілісності. У жовтні 1944 р., відразу після звільнення Києва, Київський театр опери і балету саме «Наймичкою» відкрив свій сезон, до постановки були залучені ті ж самі творчі сили, що й в Іркутську. У червні 1945 р. «Наймичку» на сцені Харківського театру опери і балету ім. М. Лисенка поставили диригент В. Пірадов, режисер В. Будневич, художник 
Г. Цапок. У другій редакції опера «Наймичка» поставлена у Донецьку в 1961 році.

Жіночі арії з опер Михайла Вериківського у трактовці Зої Христич, Зої Гайдай, Марії Литвиненко-Вольгемут та Лариси Руденко - безцінний скарб української вокальної культури.

Органічне злиття музики і поезії, правдиві сценічні образи та картини народного побуту обумовлюють унікальну цінність творів М. Веріковського на шевченківські сюжети.

Оперні шедеври композитора мають унікальну вокально-виконавську традицію та непересічну сценічну інтерпретацію, яка потребує наукового осмислення.

\title{
Література:
}

1. Бентя Ю. В. Особовий фонд композитора Михайла Вериківського (з нових надходжень ЦДАМЛМ України). Архіви України. 2012. № 4 (280). C. 76-87

2. Герасимова-Персидська Н. Образи Шевченка в оперній творчості М. Веріковського. Шевченко і музика : зб. ст. К., 1966. С. 65-77.

3. Толошняк Н. Камерна опера М. Вериківського (до 90-річчя від дня народження композитора). Музика. 1986. № 6. С. 20-21.

4. Шольп О. Лірика Шевченка і «Сотник» М. І. Вериківського. Украӥнське музикознавство. 1968. Вип. 3. С. 104-112.

DOI https://doi.org/10.30525/978-9934-26-004-9-122

\section{ТЕМА ГОЛОДОМОРУ У ХОРОВИХ ТВОРАХ УКРАЇНСЬКИХ КОМПОЗИТОРІВ ХХ-ХХІ СТОЛІТЬ}

\author{
Василенко О. В. \\ кандидат мистеитвознавства, доцент, \\ доцент кафедри історії музики \\ факультету виконавського мистецтвва та музикознавства \\ Київська муніџипальна академія музики імені Р. М. Глієра \\ м. Київ, Україна
}

Голодомор - одна із трагічних сторінок української історії $30-$ х років минулого століття. Лише в епоху Незалежності зазначена тема актуалізується і стає предметом творчості українських композиторів. У 90-х роках XX ст., за підтримки культурних діячів діаспори тема Голодомору вкорінюється у простір вітчизняних та міжнародних фестивалів сучасної музики, таких, як «Київ Музик Фест», «Контрасти», 204 